misches sowie lokal-venöses Blut wurde kurz vor und nach Eröffnen der Aortenklemme entnommen. Nach Wiedereröffnung der Aorta stieg aufgrund der hohen Konzentrationen im Blut der V. femoralis die systemische Hypoxanthin-Konzentration um das Dreifache. Die prozentuale Veränderung von Hypoxanthin korrelierte direkt proportional zur Ischämiezeit der unteren Extremitäten $(r=0,85)$. Die Veränderung im Säure-BasenStatus sowie der Lactat-Konzentration variierte stark und zeigte keine Korrelation. Systemische HypoxanthinKonzentrationen sind somit spezifische und zuverlässige Gradmesser für hypoxische Schäden.

Schliisselwörter: Gefäßchirurgie - Säure-Basen-Status - Lactat und Purine.

\title{
156. Diagnose akuter intestinaler Gefäßverschluisse mittels Serumlactat
}

\author{
G. W. Hagmüller, Ä. Janda und H. Denck \\ I. Chirurgische Abteilung, Krankenhaus Wien-Lainz, Wolkersbergenstraße 1, A-1130 Wien
}

\section{Diagnosis of Acute Intestinal Ischemia by Blood Lactate}

Summary. A prospective study with lactate in acute abdominal disease with and without intestinal ischemia was performed in 36 patients: 18 patients without ischemia showed $1.94 \pm 1.02 \mathrm{mmol} / 1 ; 18$ with ischemia were significantly higher, with $7.45 \pm 2.86$. After successful blood restoration or bowel resection, blood lactate decreased over $24 \mathrm{~h}$ to the normal value of $1.0-2.0 \mathrm{mmol}$. If lactate stays high in the first few postoperative hours, an immediate reoperation can be performed for a second look. The lactate difference in lower-extremity ischemia, with $1.72 \pm 0.85 \mathrm{mmol}$, is also significant. Measuring blood lactate facilitated diagnosis and helped make decisions on when a second look should be taken in intestinal ischemia.

Key words: Acute intestinal ischemia - Diagnosis - Lactate.

Zusammenfassung. In einer prospektiven Untersuchung wurde das Blutlactat bei je 18 Patienten mit und ohne intestinale Ischaemie bei akutem Abdomen verglichen. Ohne Ischaemie betrug das Lactat $1,94 \pm 1,02 \mathrm{mmol} / 1$ (Norm: 1-2 mmol). Mit Ischaemie liegt das Lactat bei 7,45 $\pm 2,86 \mathrm{mmol}$ signifikant höher (Wilcoxon). Bei erfolgreicher Operation (Embolektomie A.mes.sup., Darmresektion) normalisiert sich die Lactat verlaufskurve innerhalb von $24 \mathrm{~h}$. Damit kann einerseits eine rasche Diagnose erstellt werden und bei fehlender Tendenz des Lactats postoperativ zur Normalisierung die Indikation zum Sekond-look erleichtert werden. Der Lactatunterschied zur Femoralisembolie ist mit 1,72 $\pm 0,85$ ebenfalls signifikant.

Schlïsselwörter: Lactat - akuter Mesenterikaverschluß - Sekond-look.

\section{Therapiekonzept bei der akuten Bein-Beckenvenenthrombose}

\author{
H. Denck, M. Fischer und F. Olbert \\ I. Chirurgische Abteilung und Zentrallaboratorium Wien-Lainz, Wolkersbergenstraße 1, A-1130 Wien
}

\section{Therapeutical Concept in Deep Venous Thrombosis of the Lower Extremities}

Summary. The results of surgical thrombectomy are insatisfactory, as they only show a long-term success rate of $30-50 \%$. The reasons for this lie, on the one hand, in the evolution character of thrombosis, on the other, in such factors of uncertainty as the age of the thrombosis, how complete the removal is, and the underlying disease itself. The results may be improved by temporary arteriovenous fistula, endothelium-sparing techniques, distal removal, additional peripheral thrombolysis, and in trauma cases, the "suspended suture."

Key words: Iliofemoral thrombosis - Thrombectomy - Results.

Zusammenfassung. Die Ergebnisse der operativen Thrombektomie sind mit nur 30-50\% Langzeiterfolgen unbefriedigend. Die Ursache hierfür liegt einerseits im evolutiven Charakter der Thrombose, andererseits in den Unsicherheitsfaktoren wie Alter der Thrombose, Vollständigkeit der Ausräumung und Grundleiden. Eine Verbesserung der Ergebnisse ist möglich durch temporäre av-Fistel, endothelschonende Technik, distale Ausräumung, zusätzliche periphere Thrombolyse und in manchen Fällen (Trauma) die ,aufgehängte Naht“". Schlïsselwörter: Bein-Beckenvenenthrombose - Thrombektomie - Ergebnisse. 